\title{
Módosított Weerda-laringoszkópok alkalmazási területei a fül-orr-gégészeti gyakorlatban
}

\author{
Rovó László dr. ${ }^{1}$ - Bach Ádám dr. ${ }^{1}$ - Szakács László dr. ${ }^{1}$ \\ Bella Zsolt dr. ${ }^{1}$ - Lázár György dr. ${ }^{2}$ \\ ${ }^{1}$ Szegedi Tudományegyetem, Általános Orvostudományi Kar, \\ Fül-Orr-Gégészeti és Fej-Nyaksebészeti Klinika, Szeged \\ ${ }^{2}$ Szegedi Tudományegyetem, Általános Orvostudományi Kar, Sebészeti Klinika, Szeged
}

\begin{abstract}
A légutak és a tápcsatorna felső szakaszának általános érzéstelenítésben történő, mikroszkópasszisztált direkt endoszkópiája a fül-orr-gégészet egyik alapvető diagnosztikai és terápiás módszere. A mútéti feltárás minősége a terület jó vizualizálhatósága és a mikrosebészeti eszközök kellő manőverezhetősége szempontjából kulcsfontosságú. A leggyakrabban alkalmazott Kleinsasser-laringoszkóp mellett a retrocricoid régió feltárására a kettős lapocú Weerda-laringoszkóp előnyösebb választás. A szúk anatómiai viszonyok, az algarat és a gége több alrégiójára is kiterjedő elváltozások vizsgálata és manipulálása bizonyos esetekben azonban még ezzel az eszközzel is problémás lehet. A szerző́k négy eset kapcsán bemutatják az általuk módosított, aszimmetrikus lapochosszúságú Weerda-laringoszkópok alkalmazását. Az eszközökkel a retrocricoid régió, az algarat hátsó falának distalis és a nyelő́cső proximalis része is jól vizualizálható. A módosítások lehetővé teszik új mútéti technikák bevezetését az alkalmazott mikrosebészeti eszközök számának növelésével és még rugalmasabb használatával.
\end{abstract}

Orv Hetil. 2019; 160(7): 264-269.

Kulcsszavak: Weerda-laringoszkóp, hátsó garatfal, hypopharynx, endoszkópia, Zenker-diverticulum

\section{Application of modified Weerda laryngoscopes in the ear, nose, and throat practice}

Microscope-assisted direct endoscopy of the airways and the upper gastrointestinal tract in general anesthesia is an essential diagnostic and therapeutic method of otorhinolaryngology. The quality of surgical exploration is a key for the good visibility and maneuverability of microsurgical tools. Beside the most commonly used Kleinsasser laryngoscope, the distending Weerda laryngoscope is a more favorable option for the exploration of the retrocricoid region. Narrow anatomical situation, examination and manipulation of lesions involving several sub-regions of the hypopharynx or larynx may be problematic in some cases even with this endoscope. The authors present the application of modified Weerda laryngoscopes with asymmetric spatula length in addition with four cases. The retrocricoid region, the distal part of the posterior hypopharyngeal wall and the proximal part of the esophagus can be easily visualized with this device. The modifications allow the introduction of new surgical techniques by increasing the number of applied microsurgical devices and their maneuverability.

Keywords: Weerda laryngoscope, hypopharynx, posterior wall, endoscopy, Zenker's diverticulum

Rovó L, Bach Á, Szakács L, Bella Zs, Lázár Gy. [Application of modified Weerda laryngoscopes in the ear, nose, and throat practice]. Orv Hetil. 2019; 160(7): 264-269.

(Beérkezett: 2018. augusztus 13.; elfogadva: 2018. szeptember 10.) 


\section{Rövidítések}

$\mathrm{CNC}=($ computer numerical control $)$ mikrószámítógép vezérelt szerszámgép; EAAL = (endoscopic arytenoid abduction lateropexy) endoszkópos arytenoid abdukciós lateropexia; ETGI = (endolaryngeal thread guide instrument $)$ endolaryngealis fonalvezető eszköz; PEG = (percutaneous endoscopic gastrostoma) perkután endoszkópos gastrostoma

A légutak és a tápcsatorna felső szakaszának általános érzéstelenítésben történő, mikroszkópasszisztált direkt endoszkópiája a fül-orr-gégészet egyik alapvető diagnosztikai módszere [1-3]. Az eljárás során - mikroszkópos nagyítással vagy a nélkül - lehetôségünk nyílik az említett régiók kóros elváltozásainak identifikálására, malignitás gyanúja esetén meghatározható a tumor pontos kiterjedése, és elvégezhető a szövettani mintavétel is. Terápiás célból végzett direkt endoszkópia során pedig lehetővé válik az elváltozások vagy esetleges idegen testek transzorális eltávolítása, az algarat, a gége és a trachea manipulációja. A modern mikrolaringoszkópiát az 1960as években Oskar Kleinsasser professzor vezette be és tette népszerúvé [4]. Az általa kialakított direkt laringoszkópot az elmúlt évtizedek során több alkalommal is kisebb mértékben módosították, egyszerúsítve ezzel a beavatkozást és szélesítve annak indikációs körét. A legjelentősebb változást az 1983-ban bemutatott kettős spatulájú Weerda-laringoszkóp hozta, amely speciális kialakításával és egyénileg állítható méretével fóként a retrocricoid régió vizsgálatát és manipulációját könnyítette meg [5]. A szû́k anatómiai viszonyok, az algarat és a gége több alrégiójára is kiterjedő elváltozások vizsgálata és manipulálása bizonyos esetekben még ezzel az eszközzel is problémás lehet. A következőkben az intézetünkben

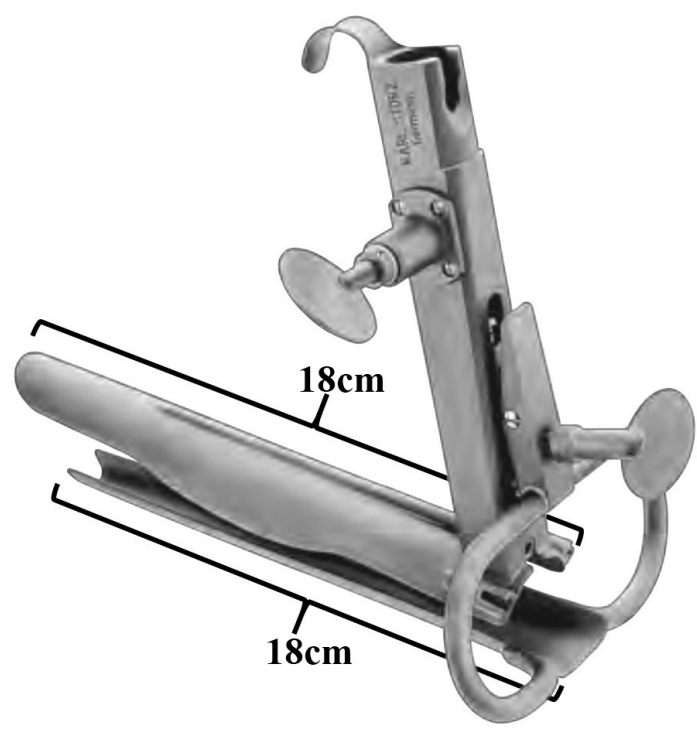

1. ábra

„8588 A” típusú Weerda-laringoszkóp $18 \mathrm{~cm}$ hosszúságú alsó és felső lapoccal (Az ábra a gyártó által készített, nyilvános megjelenésre jóváhagyott kép felhasználásával készült: http://epc karlstorz.com/epc/Starter.jsp?locale=EN\&practiceArea=ENT \&product=\&sid=SID-F11928D8-4F7CF198) módosított Weerda-laringoszkópok alkalmazását mutatjuk be négy eset kapcsán.

Klinikánkon a „8588 A” típusú, felnőttek számára kialakított Weerda-laringoszkóp (KARL STORZ SE \& Co. KG, Tuttlingen, Németország) lapochosszúságát változtattuk meg. Az eredeti laringoszkóp állítható alsó és felső lapoca is $18 \mathrm{~cm}$ hosszúságú, paramétereit az 1 . ábra mutatja. A módosítások CNC- (computer numerical control) megmunkálás során precíziós lézer-, illetve védőgázos hegesztéssel történtek (EMD Endoszkóp Műszer Gyártó és Kereskedelmi Kft., Debrecen, Magyarország).

\section{Módosítások}

I. Az alsó lapocot $11 \mathrm{~cm}$ hosszúságúra rövidítettük. A felső lapoc paramétereit nem változtattuk meg (2. és 3. ábra).

II. A felső lapoc méretét módosítottuk, 23 cm-re növelve meg annak hosszát. Az alsó lapoc paraméterein nem változtattunk (2. és 3. ábra).

\section{Esetbemutatás I.}

Az 57 éves férfi beteg esetében súlyos nyelési nehezítettséget okozó jobb oldali hypoharynxtumor gyanúja miatt direkt laringoszkópiát végeztünk B-, majd C-típusú Kleinsasser-laringoszkóppal, azonban a folyamat mélységi kiterjedtsége miatt a tumor pontos határai distalisan nem voltak identifikálhatók. Oesophagoscopia és nasogastricus tápszonda levezetése sem volt kivitelezhetó. Hosszított felső lapocú Weerda-laringoszkóppal (II. módosítás) feltárva az algaratot és a nyelőcsőbemenetet, egy, a nye-

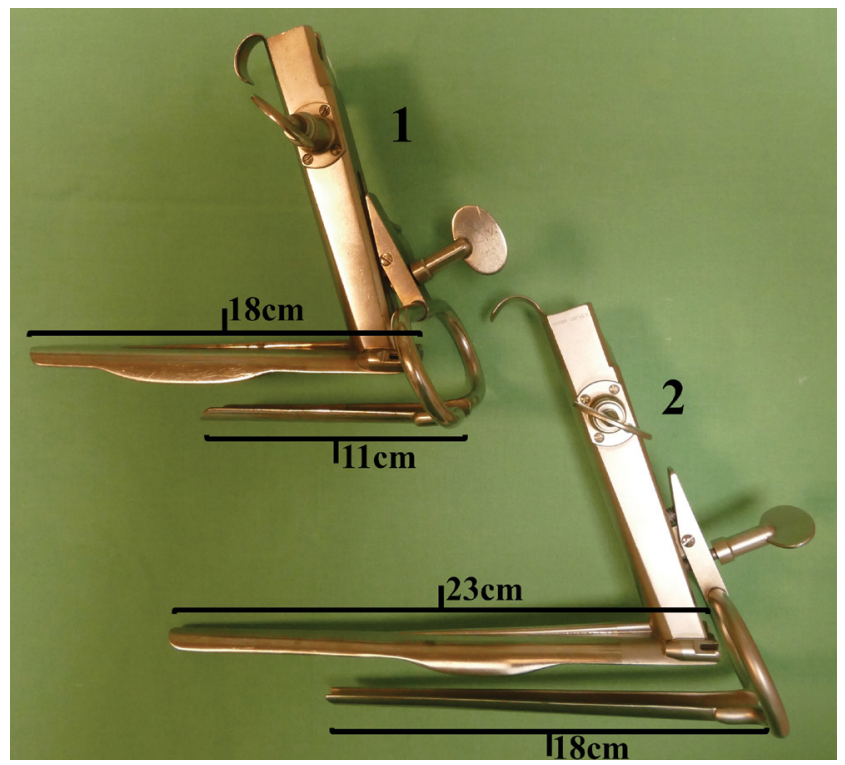

2. ábra Módosított Weerda-laringoszkópok. 1) Az alsó lapoc hosszúságát $11 \mathrm{~cm}$-re csökkentettük, a felső lapoc méretét nem változtattuk. 2) A felső lapoc hosszúságát $23 \mathrm{~cm}$-re növeltük, az alsó lapoc méreteinek módosítása nélkül 


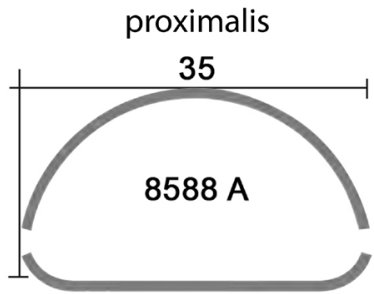

Lapocok közötti távolság: max. 30

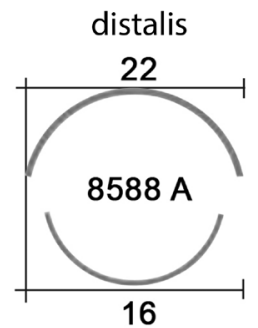

Lapocok közötti távolság: max. 65

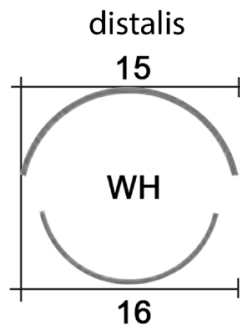

Lapocok közötti távolság: max. 65 distalis

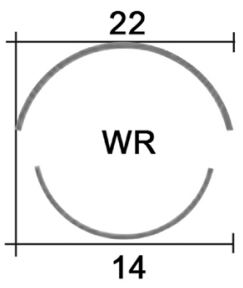

Lapocok közötti

távolság: max. 34

3. ábra

A lapocok szélessége, illetve a proximalis és distalis végei közötti maximális távolság (mm-ben megadva) az eredeti (8588 A) és a módosított (WH: a felső lapoc meghosszabítása; WR: az alsó lapoc megrövidítése) eszközök esetében

lőcsőbemenetet distalis irányban $2 \mathrm{~cm}$-rel meghaladó, a praevertebralis fasciát is infiltráló, irreszekábilis, klinikailag T4b stádiumú hypopharynxtumort észleltünk. Szövettani mintavétel után a táplálás biztosítása érdekében perkután endoszkópos gastrostoma (PEG) kialakítása mellett döntöttünk. A flexibilis gasztroszkóp levezetése szintén csak laringoszkópos feltárás mellett volt elvégezhető (4-6. ábra).

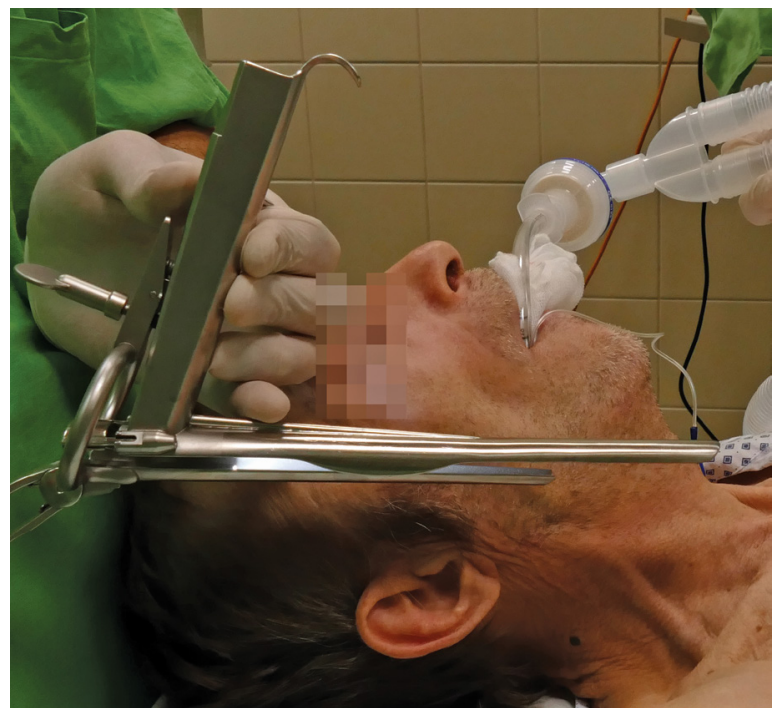

4. ábra

A nyelőcsőbemenet környékét érintő hátsó garatfali folyamatok feltárására használt, meghosszabbított felső lapoccal rendelkező laringoszkóp

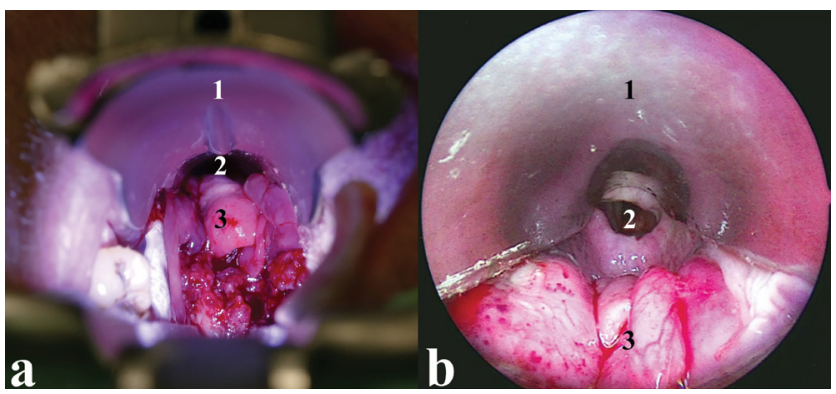

5. ábra A nyelőcső proximalis részét is infiltráló hátsó garatfali tumor képe operációs mikroszkóppal (a) és $0^{\circ}$-os endoszkóppal (b). 1) A laringoszkóp felső lapoca, 2) nyelő́cső, 3 ) hátsó garatfali tumor

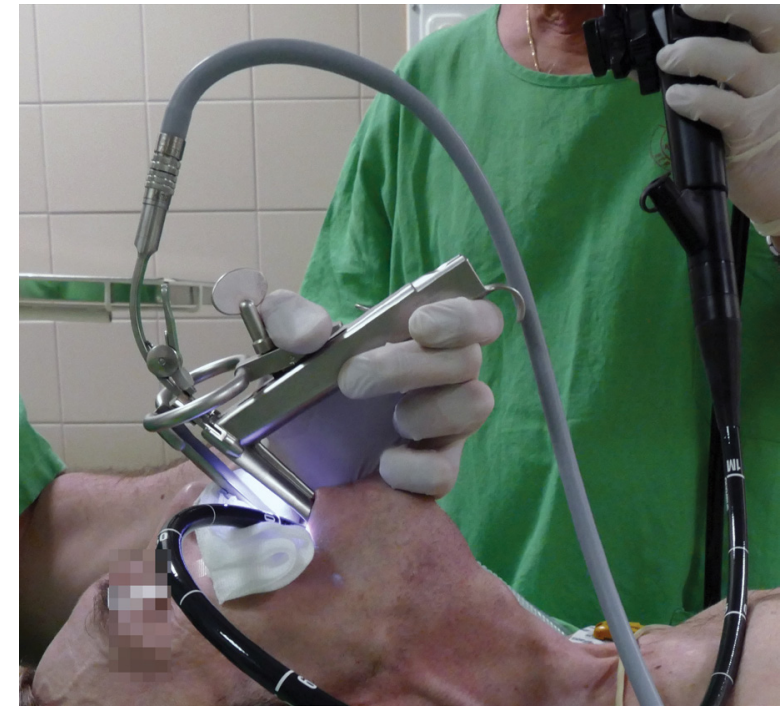

6. ábra

Flexibilis endoszkópiával asszisztált PEG-beültetés Weerdalaringoszkópon keresztül

PEG = perkután endoszkópos gastrostoma

\section{Esetbemutatás II.}

Az 59 éves férfi beteg esetében nyelési nehezítettséget okozó bal oldali mesohypopharynxtumor gyanúja miatt direkt laringoszkópiát végeztünk. Az algarat feltárását a hosszított felső lapocú Weerda-laringoszkóppal (II. módosítás) végeztük, így látható vált egy bal oldali dominanciájú, a középvonalat is meghaladó $2,5-3 \mathrm{~cm}$ átmérőjü, klinikailag T2-es stádiumú, a nyelőcsőbemenetet körülbelül $1 \mathrm{~cm}$-re megközelítő hátsó garatfali hypopharynxtumor. Az elváltozást elektromos késsel, folyamatos endoszkópos kontroll mellett, szélesen az épben reszekáltuk (7. ábra). A szövettani vizsgálat tumormentes reszekciós széleket írt le.

\section{Esetbemutatás III.}

Az 51 éves férfi beteg évek óta fokozódó dysphagia és ételregurgitatio miatt került kivizsgálásra. A kontrasztanyagos nyeléses röntgenvizsgálat és az oesophagogastroscopia $3 \mathrm{~cm}$ hosszúságú Zenker-diverticulumot iga- 


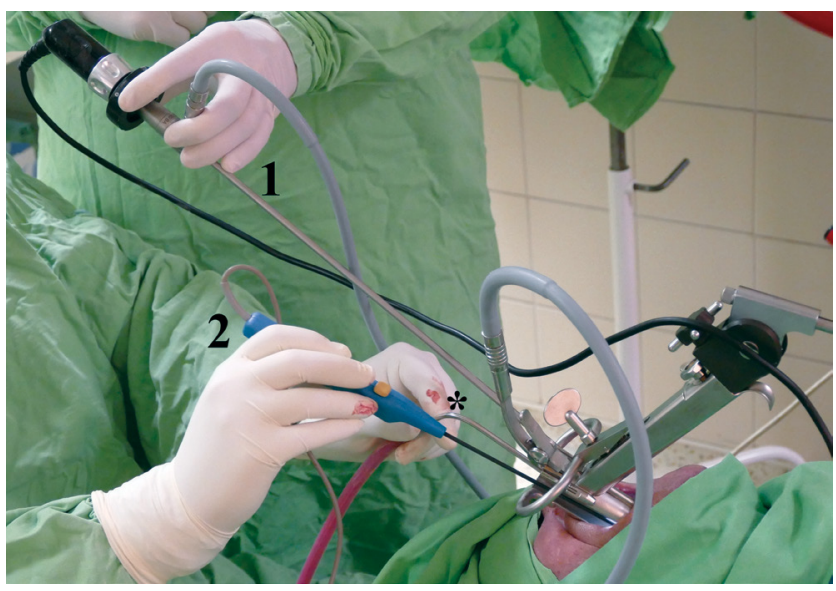

7. ábra

Hátsó garatfali tumor endoszkópos eltávolítása. Három eszköz egyidejű bevezetése a laringoszkópon keresztül: 1) endoszkóp 2) unipoláris elektromos kés, *: szívó

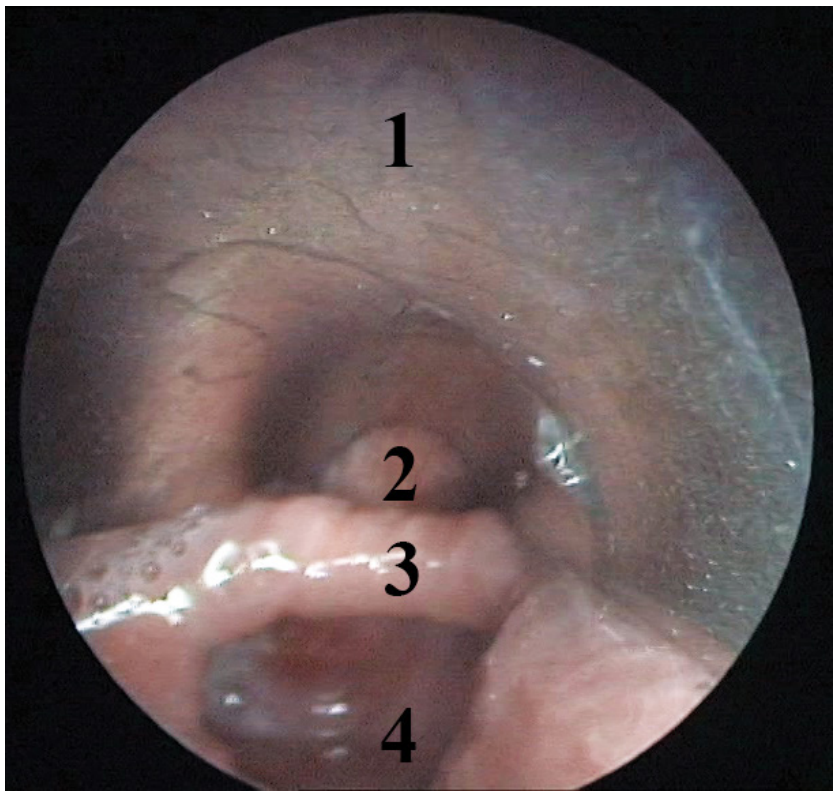

8. ábra

Zenker-diverticulum feltárása Weerda-laringoszkóppal. 1) A la ringoszkóp felső lapoca, 2) nyelőcső, 3 ) a nyelőcsövet és a diverticulumot elválasztó septum, 4) Zenker-diverticulum

zolt. Mütéti megoldásként endoszkópos lézeres diverticulotomia mellett döntöttünk. A hypopharynxot hosszított felső lapocú Weerda-laringoszkóppal (II. módosítás) tártuk fel, amivel egy időben látótérbe hozható volt a nyelőcső és a diverticulum szájadéka is (8. ábra). Ezt követően a nyelőcsövet és a diverticulumot elválasztó septumot $\mathrm{CO}_{2}$-lézerrel reszekáltuk.

\section{Esetbemutatás IV.}

A 39 éves nőbeteg esetében kétoldali pajzsmirigymütétet követően kialakult kétoldali gégefélbénulást és következményes nehézlégzést diagnosztizáltunk. Direkt endo- szkópiát és a hangrés tágítására a bal oldali paramedián állású hangajak endoszkópos arytenoid abdukciós lateropexiáját (EAAL) végeztük [6-9]. A beavatkozáshoz rövidített alsó lapocú Weerda-laringoszkópot (I. módosítás) használtunk (9. ábra).

\section{Megbeszélés}

Az endoszkópos beavatkozások során a mútéti feltárás minősége kulcsfontosságú kérdés. Mikrolaringoszkópia során célszerü a lehető legszélesebb feltárást biztosító, még könnyedén behelyezhető endoszkóp alkalmazása. Ehhez laringoszkópok széles tárháza áll rendelkezésre, azonban nincs olyan eszköz, amely minden szituációban optimális feltárást biztosítana. Szükségszerü, hogy az operatőr több laringoszkóp rutinszerű használatában jártas legyen, így az adott mútéti szituációban lehetősége adódik az optimális feltárást biztosító eszköz kiválasztására. Célszerü, hogy a laringoszkóp proximalis vége minél szélesebb legyen, lehetővé téve a binocularis látást és minimum két mikrosebészeti múszer egyidejű használatát. Az eredeti Kleinsasser-laringoszkóp proximalis nyílásának átmérője relatíve kicsi, és distalis irányban még tovább csökken. Keresztmetszeti formája lekerekített, így nem felel meg a glottis anatómiájának (ez pedig megnehezíti az elülső commissura látótérbe hozását is). További hátránya, hogy alakja, illetve distalis végének nyílása a betegek különböző anatómiájához nem alakítható [10].

Ezeket a hiányosságokat jól áthidalja az 1983-ban bemutatott Weerda-laringoszkóp, mely fóként a Zenkerdiverticulumok endoszkópos kezelésében kapott helyet, de más indikációban is leírták már az alkalmazását [11, 12]. Ilyen például a lingualis tonsillotomia, hypopharynx-

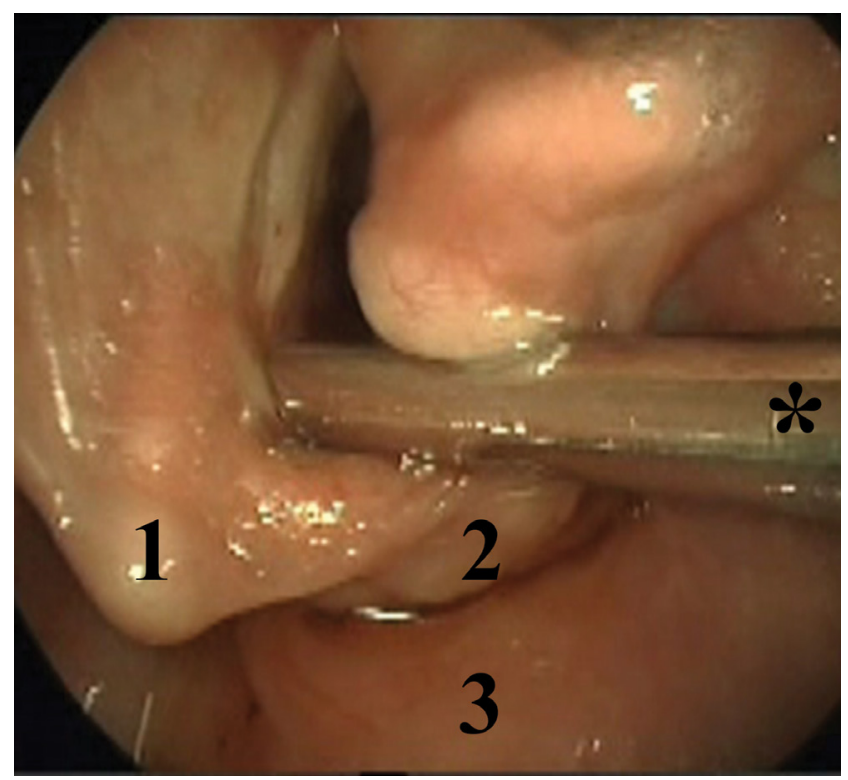

9. ábra $\mid$ Jól vizualizálható retrocricoid régió bal oldali endoszkópos arytenoid abdukciós lateropexia közben. 1) Bal oldali kannaporc, 2) retrocricoid terület, 3) hátsó garatfal, *: endolaryngealis fonalvezető eszköz 
diverticulum eltávolítása laryngectomiát követően, nyelőcsőpolip eltávolítása, gégeplasztika, idegentest-eltávolítás vagy a cricopharyngealis izom endoszkópos myotomiája [13-19].

A feltáró fő előnye, hogy mérete egyénileg állítható még a behelyezés után is. Az áttekinthető mưtéti terület nagysága jelentősen nagyobb a Kleinsasser-laringoszkóphoz képest, amelyet tovább növel a kedvező betekintési szög is, lehetővé téve a retrocricoid régió és a hátsó garatfal áttekintését. A Weerda-laringoszkóp szélesen eltartja a lágyrészeket, és lehetőséget biztosít az endoszkópon át bevezetett eszközök számának növelésére és szabadabb mozgatására. A laringoszkópon keresztül tracheoscopia, bronchoscopia, oesophagoscopia és intubáció is végezhető [20]. Megfelelő gyakorlattal tehát a Weerda-laringoszkóp igen sokféle beavatkozás során hasznos lehet. Mélyen az algaratban, a nyelőcsőbemenethez közeli vagy a nyelőcsőbemenetet meghaladó algarati folyamatok vizualizációja azonban még ezzel az eszközzel is akadályba ütközhet. Tapasztalataink szerint ez a probléma a lapocok hosszúságának aszimmetrikus módosításával kiküszöbölhető.

A hátsó garatfalon elhelyezkedő tumorok a hypopharynx malignus elváltozásainak mindössze 7\%-át adják [21]. A relatíve alacsony esetszám miatt a mai napig nem alakult ki nemzetközi konszenzus az optimális kezelési stratégiáról. A nagy morbiditással járó, külső feltárásból végzett részleges garatreszekciót kiváltó transzorális endoszkópos mütét módosított Weerda-laringoszkóp segítségével könnyebben kivitelezhető bonyolult feltáróeszközök nélkül is [22]. A megfelelő endoszkópos technikával lehető válik az ideiglenes tracheostoma és a garatban visszamaradó lágyrészdefektus lebenyes pótlásának elkerülése. Mindez hozzájárul a beteg nyelési funkciójának mihamarabbi rehabilitációjához is (II. eset). Módosított Weerda-laringoszkóp alkalmazásával áthidalható a felső tápcsatorna súlyos fokú obstrukciója, ezzel egyetemben a PEG-behelyezés egyik abszolút kontraindikációja is (I. eset). Mivel az eszközzel a nyelöcső proximalis területe is feltárható, a nyelőcsőben végzett endoszkópos beavatkozások spektruma is szélesebbé válik. Hazánkban először munkacsoportunk használt endoszkópos varrógépet diverticulostoma képzéséhez Zenker-diverticulum esetén $[12,23]$. Az endoszkópos eljárás előnye a rövidebb narkózis és mütéti idő, a diverticulumperforáció és a nervus recurrens sérülésének kisebb veszélye és a külső műtéti heg hiánya. A beavatkozás utáni táplálás korán elkezdhető, a kórházi ápolás lényegesen lerövidül. A harmadik esetben végzett lézeres diverticulotomia szintén megköveteli a nyelőcsövet és a diverticulumot elválasztó septum széles feltárását, melyre a módosított Weerda-largingoszkóp szintén kiválóan alkalmas [24]. A negyedik esetben ismertetett endoszkópos arytenoid abdukciós lateropexia Kleinsasser-laringoszkóppal nem kivitelezhető, és a szimmetrikus lapochosszúságú Weerda-laringoszkóp sem optimális eszköz a feltáráshoz. A relatíve hosszú alsó lapoc ugyanis részben elfoglalja a retrocricoid teret, megnehezítve a fonalvezető eszköz (endolaryngeal thread guide instrument, ETGI; Mega Kft., Szeged) szabad mozgatását. Ez a probléma az aszimmetrikus lapochosszúságú laringoszkóppal könnyedén kiküszöbölhető, lehetőséget teremtve a minimálisan invazív, reverzibilis EAAL gyors elvégzésére [6-9].

\section{Következtetés}

Elmondható, hogy amennyiben a retrocricoid régió vagy a hypopharynx proximalis része a beavatkozás célterülete, az alsó száron rövidített Weerda-laringoszkóp alkalmazása javasolt. A hátsó garatfal distalisabb területeit és a nyelőcső proximalis szakaszát érintő elváltozások látótérbe hozására a hosszított felső lapoccal rendelkező Weerda-laringoszkóp a megfelelő választás. A lapocok eltérő hosszúsága lehetővé teszi az alkalmazott (mikro) sebészeti eszközök számának növelését és az eszközök még rugalmasabb használatát. A betegek életminősége szempontjából a szerv- és funkciómegtartó mütétek előtérbe helyezése kiemelt fontosságú. A kevésbé invazív, endoszkópos technikák alkalmazását ezért mindenképpen érdemes előnyben részesíteni. A szúk anatómiai viszonyok miatt e mütétek alapfeltétele a mútéti terület jó vizualizálhatósága és az eszközök kellő manőverezhetősége. A rutinszerúen használt feltárók különleges igényekre történő egyszerü módosítása lehetővé teszi új mütéti technikák bevezetését, és emellett szükségtelenné teszi a bonyolult és jelentősen drágább mútéti eszközök alkalmazását.

Anyagi támogatás: A közlemény megírása, illetve a kapcsolódó kutatómunka anyagi támogatásban nem részesült.

Szerzôi munkamegosztás: R. L.: A bemutatott mütéti eszköz kialakítása, mütétek elvégzése, lektorálás, szakmai tanácsadás. B. Á.: A kézirat megszövegezése, irodalmi áttekintés, mütétek elvégzése, a mütétek dokumentálása. Sz. L.: Mütétek elvégzése, a mútétek dokumentálása. B. Zs.: Szakmai tanácsadás. L. Gy.: Mütétek elvégzése, szakmai tanácsadás. A cikk végleges változatát valamenynyi szerző elolvasta és jóváhagyta.

Érdekeltségek: A szerzőknek nincsenek érdekeltségeik.

\section{Irodalom}

[1] Kirsten A. Autoskopie des Larynx und der Trachea. Arch Laryngol Rhinol. 1895; 3: 156-164.

[2] Killian G. Die Schwebelaryngoskopie. Arch Laryngol Rhinol. 1912; $26: 277$

[3] Brünning W, Albrecht W. Direkte Endoskopie der Luft- und Speisewege. Ferdinand Enke, Stuttgart, 1915.

[4] Kleinsasser O. Weitere technische Entwicklung und erste Ergebnisse der „endolaryngealen Mikrochirurgie“. Z Laryng Rhinol Otol. 1965; 44: 711-727. 
[5] Weerda H, Pedersen P, Meuret G. A new distending laryngoscope for diagnosis and microsurgery of the larynx. Laryngoscope 1983; 93: 639-641.

[6] Rovó L, Madani S, Sztanó B, et al. A new thread guide instrument for endoscopic arytenoid lateropexy. Laryngoscope 2010 120: 2002-2007.

[7] Szakács L, Sztanó B, Matievics V, et al. A comparison between transoral glottis-widening techniques for bilateral vocal fold immobility. Laryngoscope 2015; 125: 2522-2529.

[8] Sandhu GS, Nouraei SAR, Rovó L, et al. Bilateral impaired vocal cord mobility. In: Sandhu GS, Nouraei SAR. (eds.) Laryngeal and tracheobronchial stenosis. Plural Publishing, San Diego, CA, 2016; pp. 195-227.

[9] Rovó L, Jóri J, Brzózka M, et al. Airway complication after thyroid surgery: minimally invasive management of bilateral recurrent nerve injury. Laryngoscope 2000; 110: 140-144.

[10] Friedrich G. Microphonosurgery using cold instruments. In: Remacle M, Eckel HE. (eds.) Surgery of larynx and trachea. Springer Verlag, Berlin, Heidelberg, 2010; pp. 45-50.

[11] Jaramillo MJ, McLay KA, McAteer D. Long-term clinico-radiological assessment of endoscopic stapling of pharyngeal pouch: a series of cases. J Laryngol Otol. 2001; 115: 462-466.

[12] Lázár G, Rovó L, Szentpáli K, et al. Endoscopic stapling diverticulostomy for Zenker diverticulum. [Endoszkópos varrógéppel képzett diverticulostoma a Zenker-diverticulum kezelésére.] Orv Hetil. 2004; 145: 15-17. [Hungarian]

[13] Woodson BT. Innovative technique for lingual tonsillectomy and midline posterior glossectomy for obstructive sleep apnea. Oper Tech Otolaryngol Head Neck Surg. 2007; 18: 20-28

[14] Pitzer G, Oursin C, Wolfensberger M. Anterior pseudodiverticulum after laryngectomy. [Anteriores Pseudodivertikel nach Laryngektomie.] HNO 1998; 46: 60-63. [German]

[15] McLean JN, DelGaudio JM. Endoscopic resection of a giant esophageal polyp: case report and review of the literature. Am J Otolaryngol. 2007; 28: 115-117.
[16] Herrmann IF, Arce-Recio S. Special techniques for resolving as piration problems. Oper Tech Otolaryngol Head Neck Surg. 1998; 9: 180-191.

[17] Kucharczuk JC, Kaiser LR, Marshall MB. Weerda diverticuloscope: novel use to remove embedded esophageal foreign bodies. Ann Thorac Surg. 2003; 76: 1276-1278.

[18] Swanson PB, Apicella SA, Rosen CA. Removal of a triple-barbed fishhook from the hypopharynx with microlaryngoscopy. Am J Otolaryngol. 2002; 23: 233-236.

[19] Brøndbo K. Treatment of cricopharyngeal dysfunction by endoscopic laser myotomy. Acta Otolaryngol Suppl. 2000; 543: 222224.

[20] Sapundzhiev N. Endoscopic approach for laryngeal and hypopharyngeal malignancies with the Weerda diverticuloscope. J IMAB 2010; 16: 44-47.

[21] Rimner A, Lee N, Zelefsky MJ. Cancer of the hypopharynx. In: Hoppe RT, Phillips TL, Roach M. (eds.) Textbook of radiation oncology. 3rd edn. Saunders, Philadelphia, PA, 2010; pp. 664780.

[22] Fernández-Fernández MM, Montes-Jovellar L, Parente Arias PL, et al. TransOral endoscopic UltraSonic Surgery (TOUSS): a preliminary report of a novel robotless alternative to TORS. Eur Arch Otorhinolaryngol. 2015; 272: 3785-3791.

[23] Lázár Gy, Szentpáli K, Rovó L. Endoscopic stapling diverticulostomy for Zenker diverticulum. [Zenker-diverticulum sikeres kezelése endoscopos diverticulostoma képzéssel.] Magyar Sebész Társaság Endoscopos Szekciójának VIII. Kongresszusa, Abstract-könyv, Székesfehérvár, 2001; 63. [Hungarian]

[24] Barton MD, Detwiller KY, Palmer AD, et al. The safety and efficacy of endoscopic Zenker's diverticulotomy: a cohort study. Laryngoscope 2016; 126: 2705-2710.

(Bach Ádám dr., Szeged, Tisza Lajos krt. 111., 6725 e-mail: bach.adam@med.u-szeged.hu)

\section{MEGHÍVÓ}

\section{A Magyar Hematológiai és Transzfúziológiai Társaság vezetősége tisztelettel meghívja valamennyi tagját a $\mathbf{2 7}$. Kongresszusára.}

HELYSZÍN: Kodály Központ

(7622 Pécs, Breuer Marcell sétány 4.)

IDŐPONT: 2019. május 23-25.

A kongresszus weboldala már elérhető a www.regio10.hu/mhtt2019 címen, itt folyamatosan tájékoztatást lehet kapni a kongresszusi tudnivalókról.

\section{FONTOS HATÁRIDŐ:}

Korai regisztráció: 2019. február 28.

\section{A KONFERENCIA KIEMELT TÉMÁI:}

- Aktualitások a heveny leukémiák diagnosztikájában és kezelésében.

- A myeloproliferatív neoplasmák kezelési ajánlásai (CML, PV, ET, MF).

- Szemléletváltozás a lymphoproliferatív betegségek terápiájában.

- Az allogén haemopoetikus őssejt-transzplantáció újdonságai.

- A vérzékenység aktualitásai (föként új kezelési lehetőségek a haemophiliában).

- Kihívások a transzfuziológiában a XXI. században. 